\title{
MONITORING THE CONGESTION OF URBAN PUBLIC TRANSPORT SYSTEMS FOR THE POSSIBILITY OF INTRODUCING THE CROWD SHIPPING DELIVERY IN BRATISLAVA
}

\author{
Andrii Galkin \\ O. M. Beketov National University of Urban Economy in Kharkiv, Department of Transport Systems and Logistics, \\ 17 Bazhanova str., 61001 Kharkiv, Ukraine, andriy.galkin@kname.edu.ua (corresponding author)
}

Tibor Schlosser

Slovak Technical University in Bratislava, Department of Transportation Engineering, Radlinskeho 11, 81005 Bratislava, Slovakia, EU, tibor.schlosser@stuba.sk

\section{Silvia Cápayová}

Slovak Technical University in Bratislava, Department of Transportation Engineering, Radlinskeho 11, 81005 Bratislava, Slovakia, EU, silvia.capayova@stuba.sk

Denis Kopytkov

O. M. Beketov National University of Urban Economy in Kharkiv, Department of Transport Systems and Logistics, 17 Bazhanova str., 61001 Kharkiv, Ukraine, kopytkov_dm@ukr.net

\section{Ganna Samchuk}

O. M. Beketov National University of Urban Economy in Kharkiv, Department of Transport Systems and Logistics, 17 Bazhanova str., 61001 Kharkiv, Ukraine, ganna.samchuk@gmail.com

\section{Dominika Hodáková}

Slovak Technical University in Bratislava, Department of Transportation Engineering, Radlinskeho 11, 81005 Bratislava, Slovakia, EU, dominika.hodakova@stuba.sk

Keywords: urban public transport, crowdsourcing, visual study, passenger flows, crowd shipping Abstract: The aim is to study the congestion of urban passenger transport in the historical part of Bratislava for the possibility of introducing crowdsourcing technology. The visual methods of examination are used in work. According to the results of the study, data were obtained on the congestion of urban passenger transport and its distribution by hours of the day at the entrances to the historic part of the city. The obtained results indicate the possibility of using crowd shipping technology in off-peak periods. Monitoring of public transport flows in the urban core will identifying the distribution of travellers and contribute to understanding the time window for implementing crowd shipping technology during the day, minimal whit influence on the other participants of the transport process. The peak traffic load is observed on the routes passing through the Slovak National Rebellion (SNP) square in direct downtown of the city, from 8 am to 9 am and from 4-6 pm in the evening, and from 7 am to 8 am in the morning and 5-6 pm for the routes passing through the SNP bridge across the river Danube. A new way to monitoring the number of passengers in public transport was suggested. The paper provides credits for future development sharing technology and sustainable development of transport in Slovakia. The results could be usfull for transport policy and regularities for local government in Bratislava in case of apply new delivery technology.

\section{Introduction}

The intensive growth of urban freight transport leads to numerous transport links, due to which such problems arise as traffic congestion, congestion on highways, an imbalance between the need for transport services and the real capacity of roads, and the negative environmental transport impact. In order to optimise traffic flows, there is a need to develop new methods of green logistics [1]. The constant growth of urban freight transport exacerbates several problems, such as the creation of a rational system of traffic organisation, ensuring the quality of public transport services, and environmental protection. Currently, the growth rate of freight transport is significantly ahead of the growth rate of the construction of new and reconstruction of existing highways in Bratislava [2]. As a result, there is a need to address the management of traffic flows to reduce their impact on the safety of road users, reduce the load on the road network, improve the environmental situation [3]. The functioning of the urban public transport system can be improved through the introduction of new technologies such as crowd shipping [4].

Crowdsourcing is a quite new concept of first-last-mile delivery. The main difference from the traditional courier delivery is that it is not necessary to make an additional trip $[1,5]$. At the same time, overcrowding of urban passenger transport does not physically allow its use due to the loading capacity of the vehicle. To implement the 
MONITORING THE CONGESTION OF URBAN PUBLIC TRANSPORT SYSTEMS FOR THE POSSIBILITY OF INTRODUCING THE CROWD SHIPPING DELIVERY IN BRATISLAVA

Andrii Galkin; Tibor Schlosser; Silvia Cápayová; Denis Kopytkov; Ganna Samchuk; Dominika Hodáková

crowdsourcing technology, it is necessary to assess the availability of passenger transport during peak hours, when it is the busiest.

Purpose: The study is aimed at monitoring the congestion of urban passenger transport for the possibility of introducing crowdsourcing in Bratislava.

The article consists of the following sections:

- analysis of research on crowd shipping and monitoring of urban passenger transport congestion;

- $\quad$ substantiation of the method of monitoring the congestion of urban passenger transport;

- analysis of the central part of the city to determine the location of the counter;

- $\quad$ conducting research and analysis of results;

- conclusions.

\subsection{Literature review}

In on-demand urban transportation systems, it becomes extremely important to think about advanced solutions for sustainable urban transport development. Urban logistics, especially in the last mile, has been the most expensive element of the supply chain. In the context of economic transactions, this refers to the use of an object (physical good distribution or service), the consumption of which is divided into separate parts. These details are shared in Client to client networks, which are coordinated through online community-based services or through intermediaries in Business to client models [6-8]. Uber, Zipcar, Blablacar and Airbnb are trend-setting companies trying to change society by using our resources more sustainably. A recent survey of consumers in the United States found that the economies of sharing in the travel, car-sharing, finance, human resources, and music and video streaming sectors increased their revenues from $\$ 15$ billion. US up to 335 billion dollars. The USA in the following years [9].

The development of urban transport complexes in the modern sense is divided into economic, social and environmentally sustainable development, taking into account its impact on the economy, man and environment, effects (outside transport) [10]. It should be noted that the positive effect of the development of transport systems is created by reducing the total socio-economic damage in all areas of the national economy. As a result, the development of urban transport should take into account its "social value", assessment all costs for all modes of transport (including an individual), as well as losses due to noise, air pollution, time, loss of urban territory that can be used with greater benefit; energy consumption and deaths in road accidents, etc $[2,6]$. Shared mobility is seen as a promising way to reduce road congestion and any emissions [5,6]. In their paper, [7] defined sustainable development as «a process of change in which the use of resources, investment directions, technological progress, and institutional change are in harmony and provide opportunities to meet human needs now and in the future». The literature offers a number of case studies [8,9] on the impact [10], road behaviour [11-13] comparing car-sharing systems [14], technical documents on how to coordinate and manage the overall mobility $[1,15]$. Shared mobility is also a new concept that includes many new models. Two features common to all of these services: an element of the asset (vehicle) sharing instead of ownership, and that they rely on technology [16-19]:

Furuhata et al. [20] identified three main problems for agencies that provide joint travel for passengers. These are the development of attractive mechanisms, the correct organisation of the trip, and gaining trust among passengers in online systems. Thus, overall mobility should be able to compete with direct access to end-to-end transport provided by private cars $[21,22]$. Sustainable development of transport requires the development of activities that will lead to the greatest economic and social benefits while reducing negative environmental losses. Similarly, in the long run, the sustainable development of transport is complex and involves enormous challenges, dilemmas, difficulties, and barriers: migration, internal mobility, ageing, urbanisation and globalisation [23,24].

Minken et al. [25] include the urban cultural heritage and the accessibility of goods/services in urban freight zones as sub-targets. Methods of sustainable transport development are aimed at improving urban mobility in order to ensure access and rapid movement of the population in large urban centres [26]. Urban transport is usually associated with many modes of transport, and public transit can be carried out using different modes of transportation. Quak [27] advocates for the support of sustainable transport that provides accessibility and mobility (electric buses in combination with high-speed vehicles are more efficient alternative in terms of energy consumption instead of using regular private cars).

Existing methods of inspection of passenger flows can be classified according to a number of features. Thus, according to the duration of the period covered by the survey, there are systematic and one-time surveys [2]. Systematic is carried out daily during the entire period of operating online via Intelligent Public Transport System sensors: infrastructure [28], smartphones [29], smart vehicles [28]. Short-term research aimed to specific objects and was limited in time and parameters.

Previously, the attitude of Bratislava citizens to become a crowd-shipping courier was analysed [30]. Factors influencing the potential willingness to be nonprofessional couriers in Bratislava were established [30,31]. Moreover, freight demand for the Old Town of Bratislava was surveyed [29]. The businesses loyalty to use crowd shipping solutions was assessed. Deciding on the issue of new types of services, it is necessary to comprehensively assess their pros and cons in the urban public transport system and other related systems. To make optimal decisions, a systematic analysis of the research object, a clear understanding of the technological process, effective organisation of the interaction of participants, fast information updates, optimal service management, 
MONITORING THE CONGESTION OF URBAN PUBLIC TRANSPORT SYSTEMS FOR THE POSSIBILITY OF INTRODUCING THE CROWD SHIPPING DELIVERY IN BRATISLAVA

Andrii Galkin; Tibor Schlosser; Silvia Cápayová; Denis Kopytkov; Ganna Samchuk; Dominika Hodáková

determination of system constraints [32] are required. One of the most important links in the design of new types of services in cities is to determine the patterns of traffic flows and their distribution over sections of the road network. Monitoring of public transport flows in the urban core will identifying the distribution of transport correspondence of travellers and contribute to understanding the time window for implementing crowd shipping technology during the day, minimal whit influence on the other participants of the transport process. Literary analysis shows the absence of methods for monitoring the congestion of urban public transport systems for the possibility of introducing crowd shipping delivery. Therefore, this paper has discovered this topic.

\section{Methodology}

For the successful integration of crowdsourcing into the urban public transport system of Bratislava, it is necessary to collect the initial data. Various data collection methods that can be used. These methods differ in complexity, in the types of information that can actually be collected, and in the level of interaction between the developer of the survey and the respondents in the survey. The method of visual inspection of the interior of the vehicle was used for the study. This method allows for the estimation of large volumes of vehicles with minimal error [31]. When located at observation posts, the counters estimate the crowding of passing vehicles on this scale:

1 point - passengers occupy less than half of the seats;

2 points - passengers occupy more than half of the seats, but there are still free seats;

3 points - all seats are occupied, and up to half of the standing places are occupied;

4 points - the vehicle is full of passengers, but it is still possible to enter it;

5 points - the vehicle is full and cannot be entered.

Recommendations for the application of the method emphasise that the most reliable information can be obtained when placing counters at bus stops when using the so-called «silhouette» method of estimating the cabin crowding.

From the information about the results of the visual inspection, it is possible to assess the occupancy of the vehicle and give recommendations on the possibility of delivery of goods in them at the considered hours. The study was conducted in the morning and evening rush hours.

\section{Result and discussion}

\subsection{Analysis of the urban public transport system of Bratislava}

First, the description of the transport system of the city has been made. Bratislava has the largest urban public transport network in Slovakia. A company belonging to the local government (Dopravný podnik Bratislava) carries out all the urban transportation [32].

Surveys of traffic flow in Bratislava show that the road network operates at the capacity limit, especially in the central part, and in some parts of the network is completely exhausted. The main reason for the difficult and negative transport situation in the city is the disproportion between the level of motorisation and the density of the road network, which also significantly affects the reduction of speed and increases the commuting time [4].

The possibility of using public transport along with the transfer of passengers to deliver goods, when possible, will use the available space inside the cabin for small loads (from documents to several pallets), without any damage to passenger transport and minimal changes in work schedules. Public transport is known to be on schedule, and its presence will not in any way affect the flow of traffic, not to mention freight transport. This will partially solve one of the main problems of modern Bratislava: to relieve the historic centre from road transport and traffic flows associated with the delivery of goods or significantly reduce their impact; increase the number of interested working people; caring for the environment, etc.

\subsection{A visual study of urban passenger transport congestion}

In autumn 2019, in the Old Town, Bratislava, a study of passenger traffic in the historical part of the city was carried out using the visual method. The Old Town was chosen as the study area. It is a relatively small pedestrian area, and almost all of Bratislava's main attractions are located there: on the left bank of the Danube, between the Old and New Bridges. And as it is the central part of the city, it has good transport links.

In Figure 1, the map shows the area where the study was conducted. 


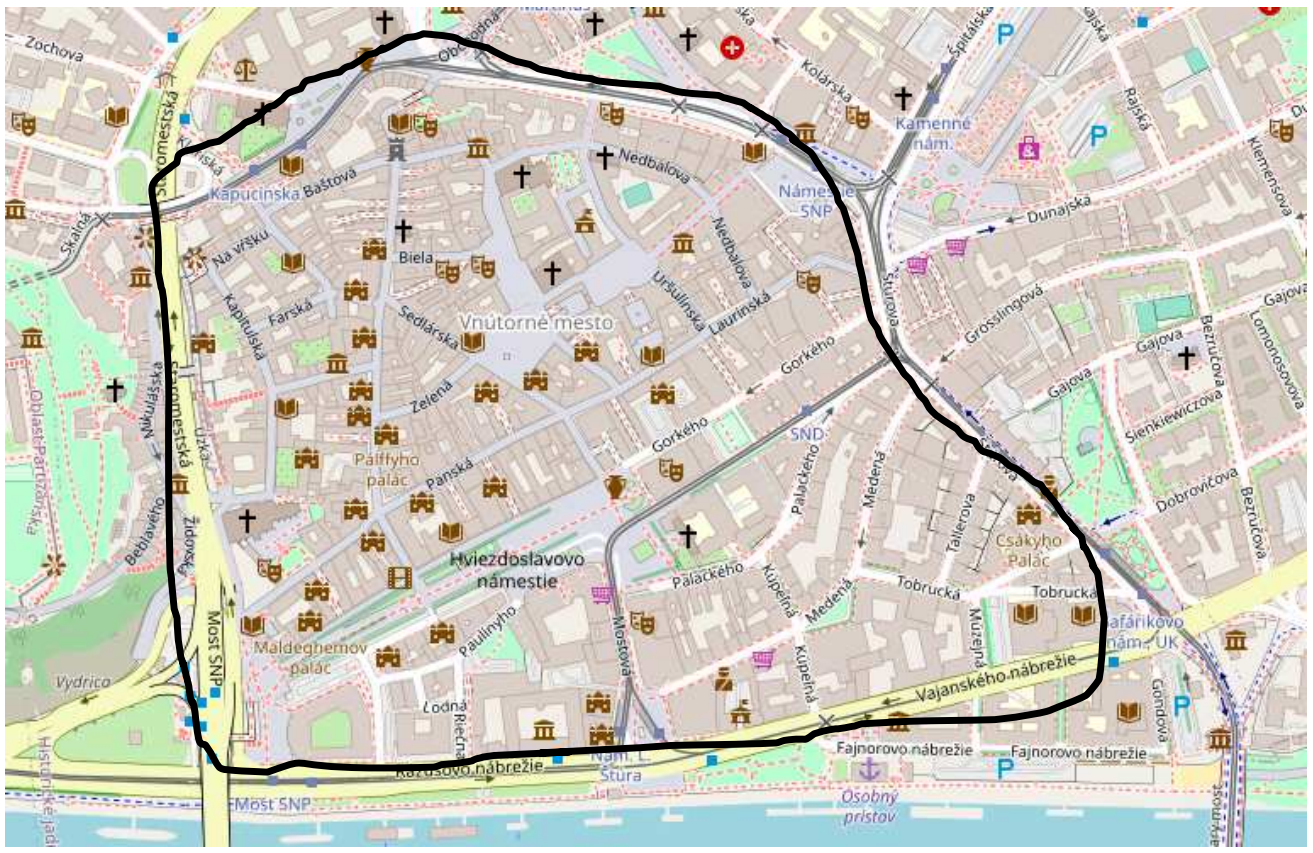

Figure 1 Map of the Old Town where the study was conducted

For the visual inspection, two bus stops were selected for the location of the counters, through which $90 \%$ of the routes in the central part of the city pass. For the visual inspection, the accountants were located at public transport stops, namely «Most SNP» and «Namestie SNP» for more efficient data recording. The selected points for fixing the crowding of the passenger transport cabin were selected taking into account the transport interchange of passenger modes of transport, location of stops, and the places of gravity for passenger traffic, and are presented in Figure 2.

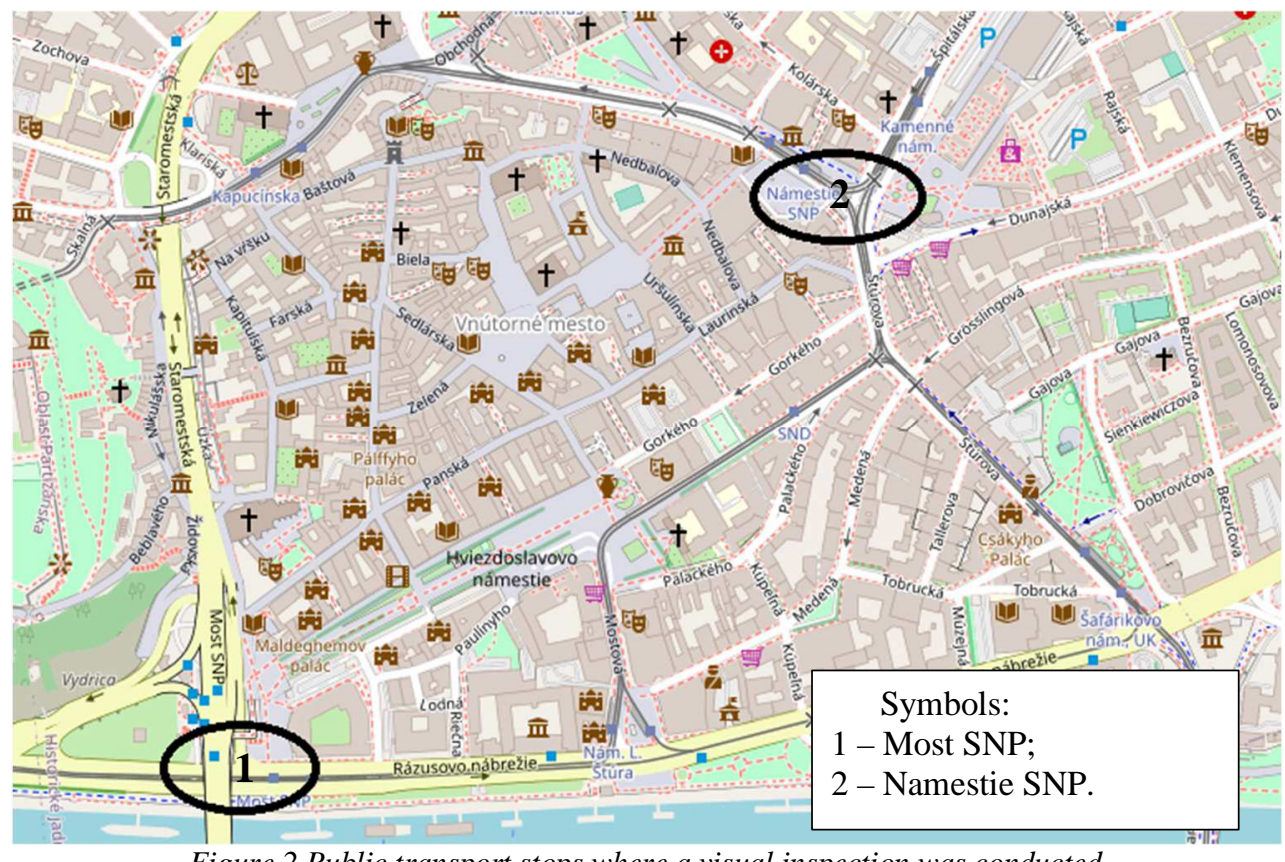

The visual method was used to compare the availability of transport during peak hours, i.e. to take into consideration the greatest load on the urban public transport system for more accurate data collection. Rush hours usually occur on weekdays when people move from their places of residence to work (from $7 \mathrm{am}$ to $9 \mathrm{am}$ ) and back (from $5 \mathrm{pm}$ to $7 \mathrm{pm}$ ). An example of a visual survey method is given in Table 1 . 
MONITORING THE CONGESTION OF URBAN PUBLIC TRANSPORT SYSTEMS FOR THE POSSIBILITY OF INTRODUCING THE CROWD SHIPPING DELIVERY IN BRATISLAVA

Andrii Galkin; Tibor Schlosser; Silvia Cápayová; Denis Kopytkov; Ganna Samchuk; Dominika Hodáková

\begin{tabular}{|c|c|c|c|c|c|}
\hline $\begin{array}{c}\text { Number of } \\
\text { observations }\end{array}$ & $\begin{array}{c}\text { Time of day, } \\
\text { hour, min }\end{array}$ & $\begin{array}{c}\text { Route } \\
\text { number }\end{array}$ & Bus brand & $\begin{array}{c}\text { Direction of } \\
\text { movement }\end{array}$ & $\begin{array}{c}\text { Cabin crowding } \\
\text { (points) }\end{array}$ \\
\hline 1 & $6: 51$ & 1 & Škoda 30T & Reverse & 3 \\
\hline 2 & $6: 52$ & 9 & Tatra K2 & Direct & 2 \\
\hline$\ldots$ & $\ldots$ & $\ldots$ & $\ldots$ & $\ldots$ & $\ldots$ \\
\hline 1048 & $10: 01$ & X6 & Škoda 30T & ח & 1 \\
\hline
\end{tabular}

Analysis of the results of the visual examination for Most SNP is shown in Figure 3, and studies for Namestie SNP are shown in Figure 4.

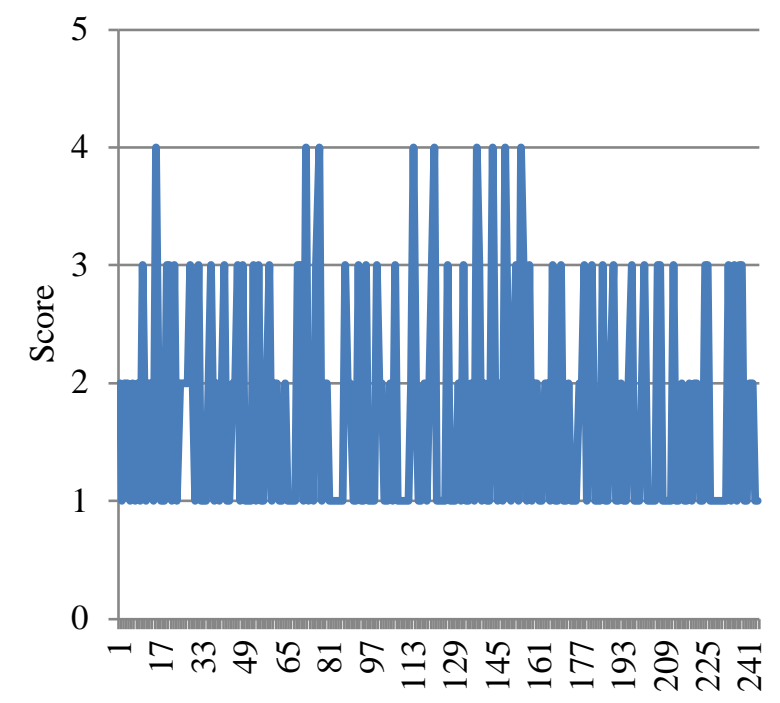

Number of studies

Monday

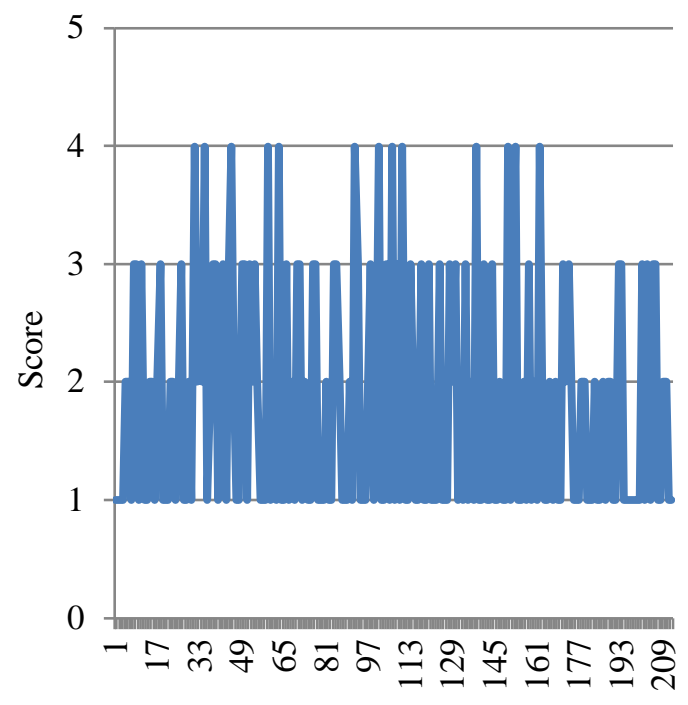

Number of studies Friday

Figure 3 Most SNP study

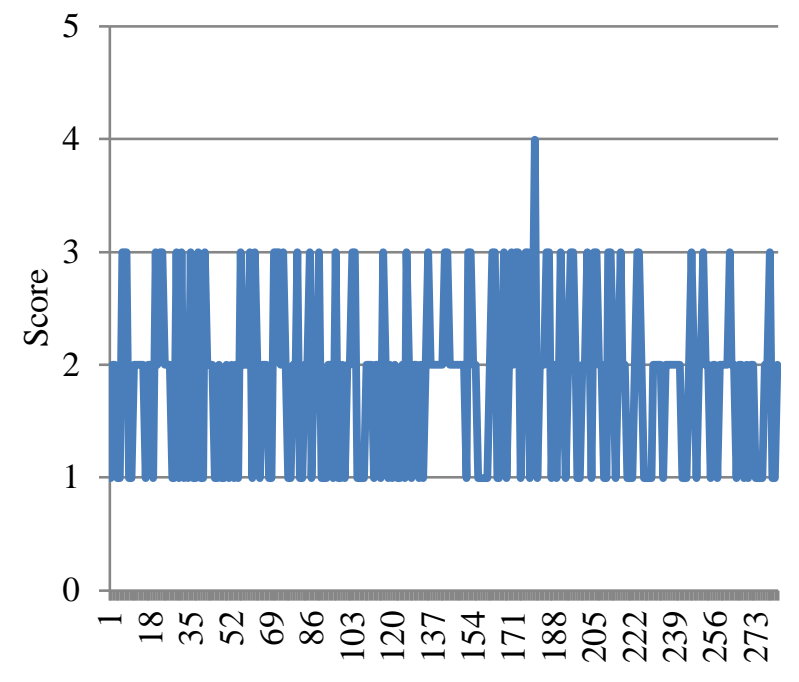

Number of studies

Monday

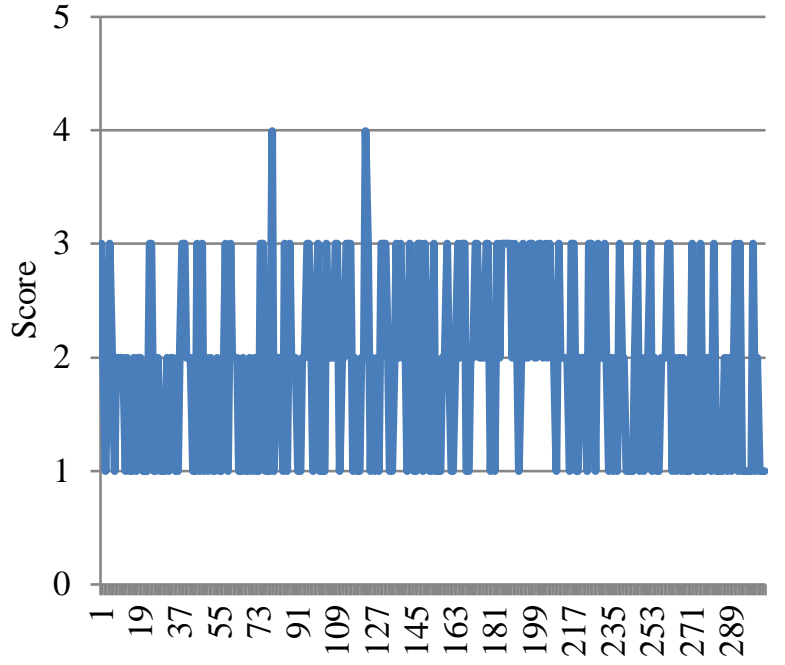

Number of studies Friday

Figure 4 Namestie SNP study 
MONITORING THE CONGESTION OF URBAN PUBLIC TRANSPORT SYSTEMS FOR THE POSSIBILITY OF INTRODUCING THE CROWD SHIPPING DELIVERY IN BRATISLAVA

Andrii Galkin; Tibor Schlosser; Silvia Cápayová; Denis Kopytkov; Ganna Samchuk; Dominika Hodáková

A total of 246 observations were recorded on Most SNP on Monday and 213 on Friday; on Namestie SNP: 305 and 284 observations, respectively. Monitoring of urban passenger traffic congestion showed that Most SNP area is busier than Namestie SNP. At this stop, the load level of 4 points was observed almost 4 times more often.

In the next step, we will determine the weighted average value at each stop within an hour. Monitoring of the urban passenger transport congestion is shown in Figure 5 and Figure 6.

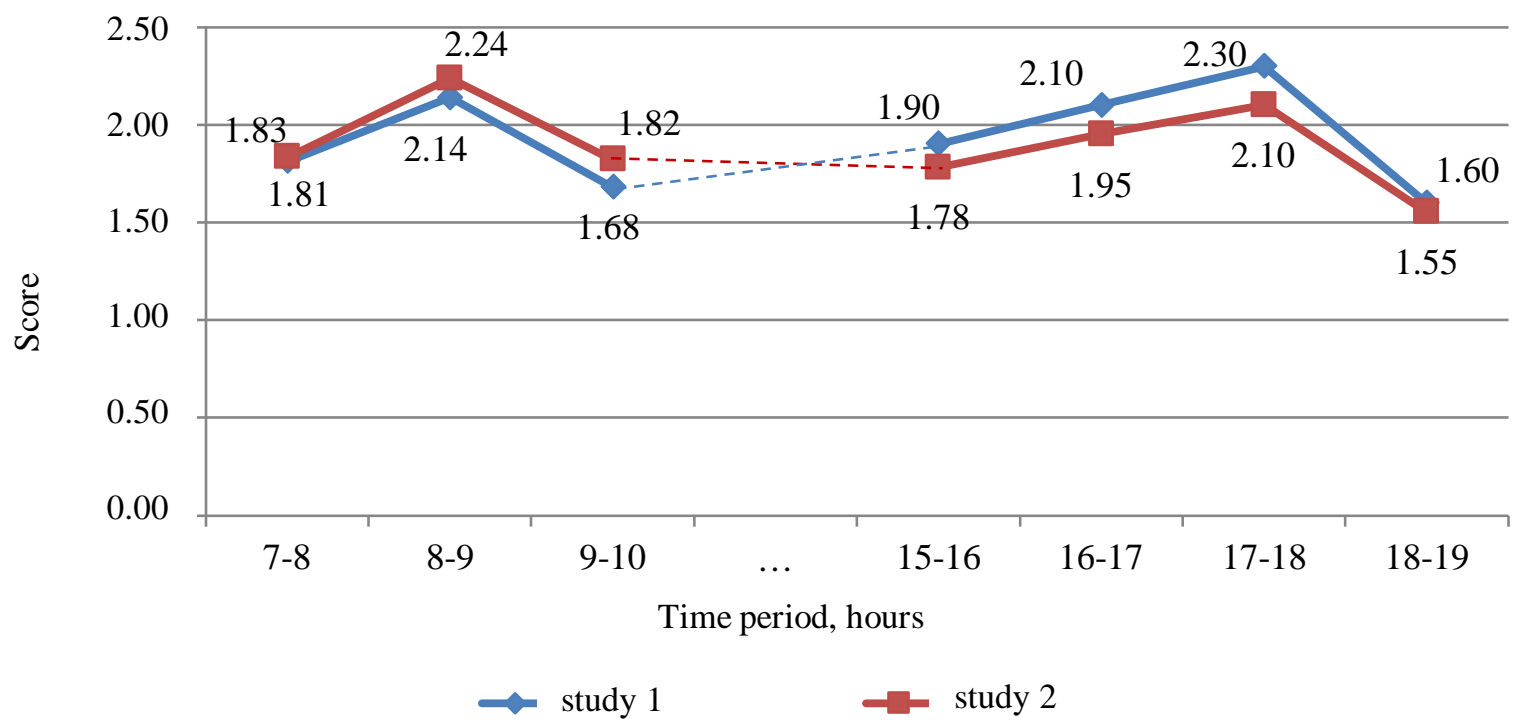

Figure 5 Change in vehicle crowding in the morning and evening rush hours (Namestie SNP)

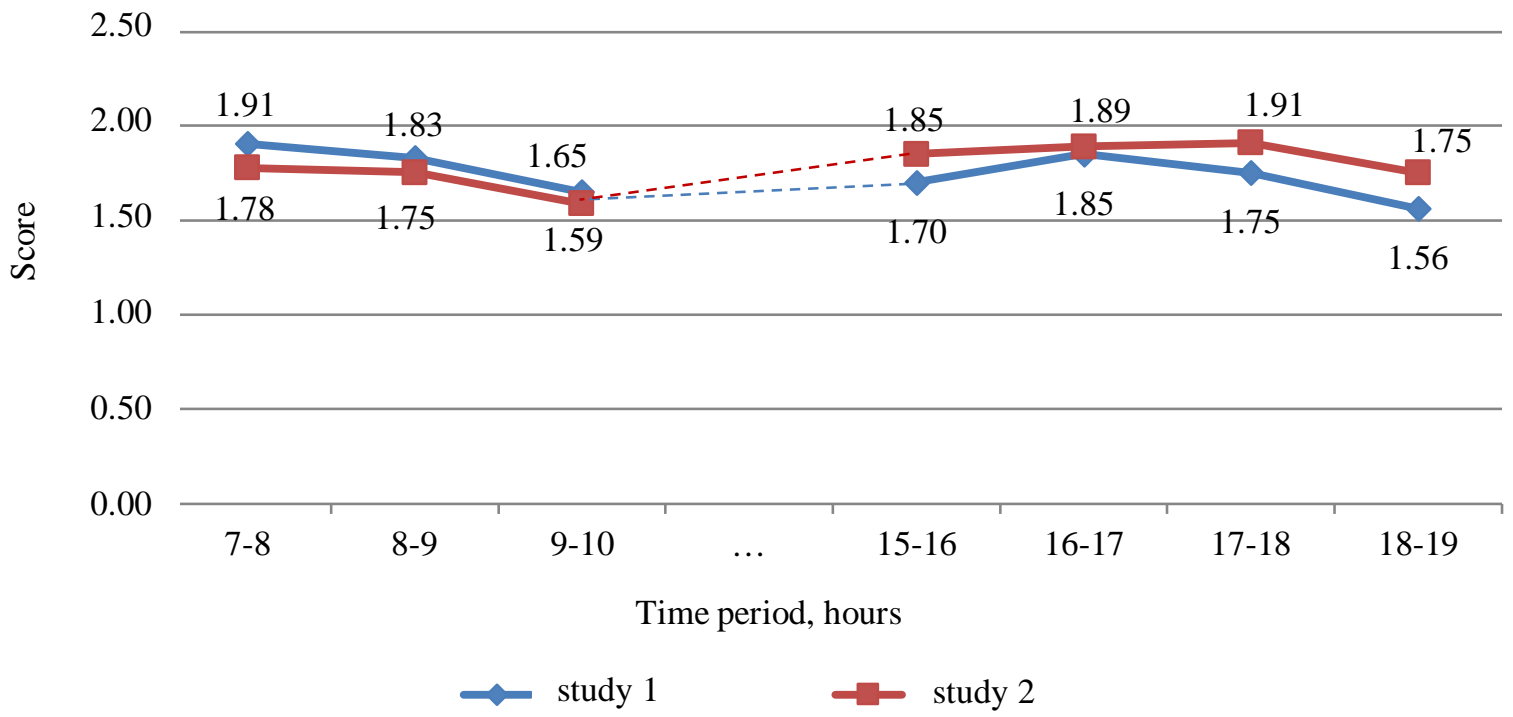

Figure 6 Change in vehicle crowding in the morning and evening rush hours (Most SNP)

Analysis of Figure 7 shows that the peak load of public transport is observed from 8 am to 9 am in the morning and 4-6 pm in the evening. At this time, it is not advisable to perform delivery in this direction, as the cabin of the vehicles is crowded.

Analysis of Figure 8 shows that the peak load of public transport is observed from 7 am to 8 am in the morning and
5-6 pm - in the evening. The load level on the routes passing through Most SNP is lower.

\section{Conclusions}

The results of the project are aimed at solving the transport problems of the historical part of Bratislava. The creation of a new freight delivery system will not limit the possibility of using existing schemes but will be a 
MONITORING THE CONGESTION OF URBAN PUBLIC TRANSPORT SYSTEMS FOR THE POSSIBILITY OF INTRODUCING THE CROWD SHIPPING DELIVERY IN BRATISLAVA

Andrii Galkin; Tibor Schlosser; Silvia Cápayová; Denis Kopytkov; Ganna Samchuk; Dominika Hodáková

supplement or alternative to it. The availability of additional options will give more flexibility in making decisions about the maintenance of the historical centre of Bratislava.

The obtained results of Fig. 5-8 indicate the possibility of using crowd shipping technology in between peak periods when the crowding of passing vehicles do not exceeds 2 points on the suggested scale in the methodology section when passengers occupy more than half of the seats, but there are still free seats. This level would be optimal for less making disturb of other passengers and suddenly raising of passenger flow on station to level 3 . The peak load of public transport is observed on routes passing through Namestie SNP from 8 am to 9 am in the morning and 4-6 pm in the evening. In this period, 3 and 4 points of crowding inside of vehicles was observed. The peak of urban transport loading is observed on the routes passing through Most SNP, and the smaller peak of urban transport loading is observed from 7 am to 8 am in the morning and 5-6 pm in the evening.

The range of data presented covers the real traffic data in Bratislava, on Monday and Friday - the most overloading days. At the same time, the ridership may vary depending on the day of the week, holidays, etc., which will affect the level of traffic. The presented approach expands the knowledge on monitoring the congestion of urban passenger transport for the possibility of crowd shipping and presents new principles of planning sustainable urban development. Monitoring of public transport flows in the urban core will identifying the distribution of transport correspondence of travellers and contribute to understanding the time window for implementing crowd shipping technology during the day, minimal whit influence on the other participants of the transport process. The visual methods of examination have their drawbacks. In particular, it does not allow to accurately determine the parameters of passenger traffic but only allows to visually assess the vehicle crowding rate of on the routes. With the help of this method, data on the occupancy vehicles on sections of the route can be obtained, but it does not allow to establish the actual volume of transported passengers on the route as a whole and the nature of the correspondence. Visual observation can be performed, as well, by drivers or conductors, who are issued the appropriate table. This method is used mainly in the sample survey. Visual methods do not provide continuous observation and are limited by human factors, accuracy, reliability. Automated methods (e.g. ITS $[28,29])$ provide processed information about passenger traffic without involving people in the direct collection of such information. The choice of specific methods for surveying passenger traffic is made based on the objects of the survey and the tasks solved on the basis of its results, taking into account local conditions, the availability of funds and the possibility of attracting resources to conduct it and process the data. Due to this, the visual method applying would be enough to obtain preliminary results on the possibility of introducing the crowd shipping delivery in Bratislava. More detailed results could be obtained in further studies on this issue.

The paper provides credits for future development sharing technology and sustainable development of transport in Slovakia. The results could be usfull for transport policy and regularities for local government in Bratislava in case of apply new delivery technology.

In the future, it is advisable to survey potential crowd shipping couriers to determine the patterns of time of their trip to the central part of the city and to establish the relationship between the traffic congestion and mobility of residents.

\section{Acknowledgement}

Special thanks to all students who participated in the survey. Publication of the paper was supported by funds from the Department of Transportation Engineering, Faculty of Civil Engineering, the Slovak University of Technology in Bratislava, Slovakia.

\section{References}

[1] MORENCY, C., VERREAULT, H., DEMERS, M.: Identification of the minimum size of the shared-car fleet required to satisfy car-driving trips in Montreal, Transportation, Vol. 42, No. 3, pp. 435-447, 2015. doi:10.1007/s11116-015-9605-2

[2] SCHLOSSER, T., CÁPAYOVÁ, S., HODÁKOVÁ, D., SCHLOSSER, P.: Evaluation of Sustainable Mobility for Urban Development Projects with Traffic Engineering Tools-Example From Bratislava, International Multidisciplinary Scientific GeoConference: SGEM, Vol. 18, No. 6.3, pp. 549-556, 2018. doi:10.5593/sgem2018/6.3/S27.071

[3] ARSLAN, A.M., AGATZ, N., KROON, L., ZUIDWIJK, R.: Crowdsourced delivery - A dynamic pickup and delivery problem with ad hoc drivers, Transportation Science, Vol. 53, No. 1, pp. 222-235, 2019. doi:10.1287/trsc.2017.0803

[4] GALKIN, A., SCHLOSSER, T., GALKINA, O., HODÁKOVÁ, D., CÁPAYOVÁ, S.: Investigating using Urban Public Transport For Freight Deliveries, Transportation Research Procedia, Vol. 39, pp. 64-73, 2019. doi:10.1016/j.trpro.2019.06.008

[5] TAYLOR, B. et al.: Between Public and Private Mobility: Examining the Rise of Technology-Enabled Transportation Services, Transportation Research Board, 2016. doi:10.17226/21875

[6] MARTIN, EW, SHAHEEN, SA: Greenhouse Gas Emission Impacts of Carsharing in North America, IEEE Transactions on Intelligent Transportation Systems, Vol. 12, No. 4, pp. 1074-1086, 2011. doi:10.1109/tits.2011.2158539

[7] BOROWIECKI, R., ROJEK, T.: Wspótcześni inicjatorzy przetomów $w$ zarządzaniu, Przegląd Organizacji, $3^{\text {th }}$ ed., pp. 21-25, 2011. 
MONITORING THE CONGESTION OF URBAN PUBLIC TRANSPORT SYSTEMS FOR THE POSSIBILITY OF INTRODUCING THE CROWD SHIPPING DELIVERY IN BRATISLAVA

Andrii Galkin; Tibor Schlosser; Silvia Cápayová; Denis Kopytkov; Ganna Samchuk; Dominika Hodáková

[8] TYNDALL, J.: Where no cars go: Free-floating carshare and inequality of access, International Journal of Sustainable Transportation, Vol. 11, No. 6, pp. 433442, 2016. doi:10.1080/15568318.2016.1266425

[9] CIARI, F., BALAC, M., BALMER, M.: Modelling the effect of different pricing schemes on free-floating carsharing travel demand: a test case for Zurich, Switzerland, Transportation, Vol. 42, No. 3, pp. 413433, 2015. doi:10.1007/s11116-015-9608-z

[10] NIJLAND, H., van MEERKERK, J.: Mobility and environmental impacts of car sharing in the Netherlands, Environmental Innovation and Societal Transitions, Vol. 23, pp. 84-91, 2017. doi:10.1016/j.eist.2017.02.001

[11] BECKER, H., CIARI, F., AXHAUSEN, KW: Modeling free-floating car-sharing use in Switzerland: A spatial regression and conditional logit approach, Transportation Research Part C: Emerging Technologies, Vol. 81, pp. 286-299, 2017. doi:10.1016/j.trc.2017.06.008

[12] KIM, J., RASOULI, S., TIMMERMANS, HJP: The effects of activity-travel context and individual attitudes on car-sharing decisions under travel time uncertainty: A hybrid choice modeling approach, Transportation Research Part D: Transport and Environment, Vol. 56, pp. 189-202, 2017. doi:10.1016/j.trd.2017.07.022

[13] KOPP, J., GERIKE, R., AXHAUSEN, KW: Do sharing people behave differently? An empirical evaluation of the distinctive mobility patterns of freefloating car-sharing members, Transportation, Vol. 42, No. 3, pp. 449-469, 2015. doi:10.1007/s11116015-9606-1

[14] NOURINEJAD, M., ROORDA, MJ: Carsharing operations policies: a comparison between one-way and two-way systems, Transportation, Vol. 42, No. 3, pp. 497-518, 2015. doi:10.1007/s11116-015-96043

[15] BICOCCHI, N., MAMEI, M.: Investigating ride sharing opportunities through mobility data analysis, Pervasive and Mobile Computing, Vol. 14, pp. 83-94, 2014. doi:10.1016/j.pmcj.2014.05.010

[16] WALLSTEN, S.: The competitive effects of the sharing economy: how is Uber changing taxis, Technology Policy Institute, Vol. 22, pp. 1-21, 2015.

[17] BIESZCZAT, A., SCHWIETERMAN, J.: Carsharing: Review of its public benefits and level of taxation, Transportation research record, Vol. 2319, No. 1, pp. 105-112, 2012.

[18] KIBA-JANIAK, M., CHEBA, K.: How Local Authorities are Engaged in Implementation of Projects Related to Passenger and Freight Transport in Order to Reduce Environmental Degradation in the City, Procedia - Social and Behavioral Sciences, 151, pp. 127-141, 2014. doi:10.1016/j.sbspro.2014.10.014

[19] VIEGAS, J., MARTINEZ, L.: Transition to Shared Mobility: How large Cities Can Deliver Inclusive
Transport Services, Corporate Partnership Board Report, International Transport Forum, Paris, 2017, [Online], Available: https://www.itfoecd.org/sites/default/files/docs/transition-sharedmobility.pdf [20 Jul 2021], 2017.

[20] FURUHATA, M., DESSOUKY, M., ORDÓÑEZ, F., BRUNET, M.-E., WANG, X., KOENIG, S.: Ridesharing: The state-of-the-art and future directions, Transportation Research Part B: Methodological, Vol. 57, pp. 28-46, 2013. doi:10.1016/j.trb.2013.08.012

[21] BALLÚS-ARMET, I., SHAHEEN, SA, CLONTS, K., WEINZIMMER, D.: Peer-to-Peer Carsharing: Exploring Public Perception and Market Characteristics in the San Francisco Bay Area, California, Transportation Research Record: Journal of the Transportation Research Board, Vol. 2416, No. 1, pp. 27-36, 2014. doi:10.3141/2416-04

[22] SHAHEEN, S., COHEN, A., ZOHDY, I.: Shared mobility resources: Helping to understand emerging shifts in transportation, Policy Briefs, Vol. 18, 2017. doi:10.7922/G2X63JT8

[23] SHAHEEN, S., CHAN, N., BANSAL, A., COHEN, A.: Shared Mobility: Definitions, Industry Developments, and Early Understanding, Berkeley: University of California, Transportation Sustainability Research Center, 2015.

[24] AGATZ, N., ERERA, A., SAVELSBERGH, M., WANG, X.: Optimisation for dynamic ride-sharing: A review, European Journal of Operational Research, Vol. 223, No. 2, pp. 295-303, 2012. doi:10.1016/j.ejor.2012.05.028

[25] MINKEN, H., JONSSON, D., SHEPHERD, S.: A Methodological Guidebook. Developing Sustainable Urban Landuse and Transport Strategies. Deliverable 14 of PROSPECTS. Leeds: Institute for Transport Studies, University of Leeds, 2003.

[26] BEHRENDS, S.: Urban freight transport sustainability. The interaction of urban freight and intermodal transport, Göteborg: Chalmers University of Technology, 2011.

[27] QUAK, H.: Sustainability of urban freight transport: Retail distribution and local regulations in cities, Rotterdam: Erasmus University, 2008.

[28] IYER, LS: AI enabled applications towards intelligent transportation, Transportation Engineering, Vol. 5, No. September, pp. 1-11, 2021. doi:10.1016/j.treng.2021.100083

[29] GUERRERO-IBÁNEZ, J., ZEADALLY, S., CONTRERAS-CASTILLO, J.: Sensor technologies for intelligent transportation systems, Sensors, Vol. 18, No. 4, pp. 1-24, 2018. doi:10.3390/s18041212

[30] GALKIN, A., SCHLOSSER, T., CAPAYOVA, S., TAKACS, J., KOPYTKOV, D.: Attitudes of Bratislava citizens to be a crowd-shipping nonprofessional courier, Transportation Research Procedia, Vol. 55, pp. 152-158, 2021. 
MONITORING THE CONGESTION OF URBAN PUBLIC TRANSPORT SYSTEMS FOR THE POSSIBILITY OF INTRODUCING THE CROWD SHIPPING DELIVERY IN BRATISLAVA

Andrii Galkin; Tibor Schlosser; Silvia Cápayová; Denis Kopytkov; Ganna Samchuk; Dominika Hodáková

[31] GALKIN, A., SCHLOSSER, T., CARDENAS, I., HODAKOVA, D., CAPAYOVA, S.: Freight Demand and Supply Assessment for Implementation of Crowdsourcing Technology: A Case Study in Bratislava, Slovakia, Sustainability, Vol. 13, No. 7, pp. 1-22, 2021. doi:10.3390/su13073865

[32] BRANIŠ, M., HODAKOVA, D., CAPAYOVA, S., SCHLOSSER, T., GALKIN, A.: Future of evaluating public transport services, International Multidisciplinary Scientific GeoConference: SGEM, Vol. 18, No. 6.3, pp. 565-571, 2018.

\section{Review process}

Single-blind peer review process. 